\title{
The production of chorionic somatomammotrophin in sheep
}

\author{
J. Martal and J. Djiane \\ Laboratoire de Physiologie de la Lactation, Institut National de la Recherche Agronomique, \\ C.N.R.Z., 78350 Jouy-en-Josas, France
}

\begin{abstract}
Summary. The production of ovine chorionic somatomammotrophin (OCS) was demonstrated in the trophoblast from Days 16-17 of pregnancy. Concentrations in the placenta rose slowly until about Day 100 when there was a rapid increase to reach $70 \pm 5 \mu \mathrm{g}$ prolactin equivalent $/ \mathrm{g}$ fresh placental tissue and $15 \pm 2 \mathrm{mg} / \mathrm{placenta}$ on Day 120. After Day 140, the concentrations decreased. It is suggested that OCS may be luteotrophic and have an effect on fetal growth.
\end{abstract}

\section{Introduction}

A placental hormone with somatotrophic and lactogenic activities has been recently purified and characterized for the sheep (Handwerger, Maurer, Barrett, Hurey \& Fellows, 1974; Martal \& Djiane, 1975, 1976; Martal, Djiane \& Delouis, 1975, 1976; Chan, Robertson \& Friesen, 1976). The hormone, ovine chorionic somatomammotrophin (OCS) or ovine placental lactogen (OPL), is homologous with the CS (or PL) of women, and its concentration, expressed as prolactin-like activity, has been measured in the blood but not in the placenta by a radioreceptor assay (Kelly, Robertson \& Friesen, 1974; Djiane \& Kann, 1975). In women, the relationship between the level of serum HCS and its placental production is not fully understood (Sciarra, Sherwood, Varna \& Lundberg, 1968; Saxena, Emerson \& Selenkow, 1969; Singer, Desjardins \& Friesen, 1970; Seppälä \& Ruoslahti, 1970; Rolschau, Date, Kristoffersen, Pedersen \& Ulrich, 1975).

With the isolation of OCS, however, the sheep would appear to be a good experimental model for study of the relationships between the synthesis and excretion of OCS, and the present study was designed to investigate the appearance of OCS and its placental variations during pregnancy.

\section{Materials and Methods}

The studies were carried out on 146 pregnant ewes of the Préalpes du Sud breed which were mated during the oestrus following removal of a progesterone-impregnated vaginal sponge (Roberts, 1966). Trophoblast material was surgically obtained at different stages of pregnancy by flushing the uterine horns with sterile saline. Placentae were also obtained at various stages of pregnancy after slaughter of the ewes.

The number of cotyledons associated with single fetuses was about 70 . Fetal cotyledons were separated from maternal cotyledons, thoroughly blotted, weighed and frozen at $-15^{\circ} \mathrm{C}$. The weight of the fetal cotyledons was determined because they have been reported to secrete OCS (Forsyth, 1972; Dubois, Martal \& Djiane, 1976). Equal amounts of fetal cotyledons were thawed and homogenized in $0.01 \mathrm{M}$-phosphate buffer, $\mathrm{pH} 7.6$ with $0.3 \mathrm{M}-\mathrm{KCl}$ and filtered through cheese-cloth. Trophoblasts were similarly thawed and homogenized. After stirring at $\mathrm{pH} 9.5$ for $4 \mathrm{~h}$ the samples were centrifuged at $12,000 \mathrm{~g}$ for $30 \mathrm{~min}$ and the lactogenic activity of supernatant fluids was measured by the radioreceptor assay described by Shiu, Kelly \& Friesen (1973) with small modifications (Djiane \& Kann, 1975). Membrane proteins were obtained from the mammary gland of lactating rabbits treated with $2 \alpha$-bromocryptine (CB 154; Sandoz). The standard curve was established by incubation of membrane receptors, labelled hormone and different concentrations of unlabelled ovine prolactin (NIH-P-S7, 24 i.u./mg) for $16 \mathrm{~h}$ at $4^{\circ} \mathrm{C}$. The placental lactogenic activity was determined by incubating 
the placental extracts or blood samples instead of the unlabelled prolactin. The specificity of the assay has been verified (Djiane \& Kann, 1975): only hormones which have lactogenic activity in the rabbit (prolactins of different species, placental lactogens, human growth hormone) are able to compete with ovine prolactin at the receptor sites. Serial dilutions of placental extracts gave a displacement curve parallel to that obtained with increasing amounts of ovine prolactin. The use of previously desaturated membrane preparations by removal of endogenous prolactin after bromocryptine treatment in vivo was found to improve the accuracy of the assay $( \pm 5 \%)$ (P. Durand \& $J$. Djiane, unpublished observations). The affinity constant for the hormone receptor interaction was $K_{a}=3.210^{9} \mathrm{M}^{-1}$, and the sensitivity of the assay ( $20 \mathrm{ng}$ ovine prolactin equiv./ml serum or placental extract) was therefore lower than with radioimmunological methods.

Serum prolactin was measured by radioimmunoassay (Kann, 1971) and the value subtracted from the total serum lactogenic activity obtained by the radioreceptor assay.

\section{Results}

OCS activity ( $\mu \mathrm{g}$ prolactin equiv./trophoblast) first appeared about Days $16-17(0,1,0 \cdot 3,0 \cdot 2$ and 1 on Days 15, 16, 17, 18 and 20, respectively) and increased to 4.5 on Day 25 and 9.5 on Day 30 of pregnancy.

The weight of the fetal cotyledons increased sharply until Day 70 of pregnancy but remained almost constant thereafter (Table 1), until a decrease began about Day 140. At parturition, the fetal cotyledonary mass was only about one-third of the weight recorded between Days 80 and 130 of pregnancy.

Table 1. Changes (mean \pm S.E.M.) of placental weight during a singleton pregnancy in Préalpes ewes

\begin{tabular}{|c|c|c|c|c|c|c|c|c|c|c|c|}
\hline Day of gestation & 50 & 62 & 75 & 85 & 100 & 110 & 115 & 120 & 130 & 140 & $\begin{array}{c}\text { At } \\
\text { term }\end{array}$ \\
\hline No. of ewes & 1 & 5 & 9 & 12 & 14 & 14 & 13 & 24 & 5 & 6 & 6 \\
\hline $\begin{array}{l}\text { Wt of fetal } \\
\text { cotyledons (g) }\end{array}$ & 51 & $\begin{array}{c}182 \pm \\
27\end{array}$ & $\underset{32}{211} \pm$ & $\frac{232}{20} \pm$ & $\begin{array}{c}228 \pm \\
11\end{array}$ & $\begin{array}{c}228 \\
14\end{array}$ & $\begin{array}{c}206 \pm \\
20\end{array}$ & $\begin{array}{c}209 \pm \\
11\end{array}$ & $\begin{array}{c}229 \pm \\
8\end{array}$ & $\begin{array}{c}175 \pm \\
24\end{array}$ & $\begin{array}{c}74 \pm \\
5\end{array}$ \\
\hline
\end{tabular}

Table 2. Changes (mean \pm S.E.M.) in OCS concentrations in the placenta of the sheep during singleton pregnancy

\begin{tabular}{lccccccc}
\hline Day of pregnancy & $70-75$ & $80-85$ & $90-95$ & 100 & $110-120$ & 140 & At term \\
\hline No. of samples & 9 & 12 & 3 & 6 & 13 & 5 & 6 \\
\hline $\begin{array}{l}\text { OCS concentration } \\
\quad \mu g / g \text { fresh tissue } \\
\text { mg/placenta }\end{array}$ & $22 \pm 4$ & $22 \pm 5$ & $20 \pm 9$ & $38 \pm 7$ & $70 \pm 5$ & $17 \pm 2$ & $10 \pm 1$ \\
\hline
\end{tabular}

The concentration of OCS per $\mathrm{g}$ fresh cotyledonary tissue increased about Day 100 , reached a maximum at Day 120 and then dropped (Table 2). A similar result was obtained when the OCS concentration was expressed as mg/placenta, but the peak at Day 120 was less pronounced (Table 2). The OCS concentration/g fresh placental tissue was similar regardless of whether 1, 2 or 3 fetuses were present, and therefore the amounts of OCS/sheep were 2- to 3-fold higher in twin and triplet pregnancies (Table 3) and a similar relationship was seen for the serum OCS concentrations. Thus, the number of fetuses in any pregnant ewe can be predicted. 
Table 3. Differences in the mean \pm S.E.M. placental weight and OCS concentrations in sheep with 1,2 or 3 fetuses on Day 110 of pregnancy

\begin{tabular}{lccc}
\hline & \multicolumn{3}{c}{ No. of fetuses } \\
\cline { 2 - 4 } & 1 & 2 & 3 \\
\hline No. of ewes & 11 & 7 & 1 \\
Placental weight (g) & $188 \pm 10$ & $361 \pm 15$ & 615 \\
$\begin{array}{l}\text { OCS concentration } \\
\text { ng/ml maternal serum }\end{array}$ & $512 \pm 65$ & $1374 \pm 199$ & 1989 \\
$\mu$ Hg/g fresh tissue & $72 \pm 5$ & $82 \pm 18$ & 65 \\
\hline
\end{tabular}

In 3 sheep, 1 fetus and 2 corpora lutea were observed on Day 120 of pregnancy. For example, one ewe showed a placental weight of $318 \mathrm{~g}$ (corresponding to a twin pregnancy) and serum OCS levels of $562 \mathrm{ng} / \mathrm{ml}$ (single pregnancy), suggesting that resorption of one fetus had taken place. A second ewe had a placental weight of $387 \mathrm{~g}$ and an OCS level of $1207 \mathrm{ng} / \mathrm{ml}$, indicating the occurrence of resorption after maximal production of OCS had been achieved. The third ewe had a placental weight of $164 \mathrm{~g}$ and an OCS level of $392 \mathrm{ng} / \mathrm{ml}$, suggesting that resorption had occurred early in pregnancy during the phase of placental growth.

Until Day 130 of pregnancy, the corpus luteum remained functional, weighing $693 \pm 26$ (S.E.M.) $\mathrm{mg}(\mathrm{N}=6)$. On Day 140 the corpus luteum weight was $375 \pm 46 \mathrm{mg}(\mathrm{N}=6)$, indicating regression. In hypoprolactinaemic pregnant ewes (injected twice daily between Days 70 and 140 with $1 \mathrm{mg}$ $2 \alpha$-bromocryptine/animal), the corpus luteum weight was only slightly lower $(561 \pm 19 \mathrm{mg}, \mathrm{N}=30$ ) than in control pregnant ewes until Day 130, at Day 140 the weight was $462 \pm 34 \mathrm{mg}(\mathrm{N}=6)$.

\section{Discussion}

Chorionic somatomammotrophin is secreted in the ewe by large binucleate PAS-positive cells in the epithelium of the chorionic villosities (Dubois et al., 1976). These cells were not observed before Days 16-17 of pregnancy by Boshier (1969). Moreover, the life-span of the corpus luteum of the cycle could not be extended by intrauterine infusion of purified OCS ( $40 \mu$ g prolactin equiv./day) from Day 12 (unpublished observations). These findings suggest that $\mathrm{OCS}$ is not the substance associated with the presence of the embryo on Day 12 known to be essential for inhibiting regression of the corpus luteum (Moor \& Rowson, 1966a,b).

It is possible that OCS is luteotrophic, like human placental lactogen (Josimovich, 1963) and prolactin in sheep (Denamur, 1973: Denamur, Martinet \& Short, 1973). In normal pregnancy, the weight of the corpus luteum remains constant until Day 130; there is only a slight (present study) or $25 \%$ (Denamur, Kann \& Short, 1971) reduction in luteal weight in sheep rendered hypoprolactinaemic or hypophysectomized after Day 60 of pregnancy, respectively, suggesting a placental luteotrophin. However, after Day 50 the ovaries are no longer required for the maintenance of gestation (Denamur \& Martinet, 1955) because the placenta secretes large amounts of progesterone (Bassett, Oxborrow, Smith \& Thorburn, 1969). Nothing is known about the relationship between OCS and progesterone secretion in the placenta.

The total weight of the placenta increases rapidly until Day 80 of pregnancy and then remains constant until Day 130 (Alexander, 1964). The concentration of OCS is therefore not proportional to placental weight because it is low before Day 80 and rises between Days 80 and 130. Nothing is known about the molecular mechanism of OCS synthesis for comparison with information available for HCS (Boime, Boguslawski \& Caine, 1975; Hubert \& Cédart, 1975).

After Day 140 of pregnancy, placental weight and OCS production decrease rapidly, the latter slightly earlier than the former, and both are much reduced at parturition. The mechanism of placental regression is not known, but the spectacular involution of the placenta before parturition suggests lysosomal activity. Lysosomes are known to be labilized under the influence of oestrogens (Szego, 
1974; Gustavii, 1975) and maternal oestrogens are rapidly increasing at term (Challis, 1971). Prostaglandins may also be involved since the concentration of PGF-2 $\alpha$ in the maternal cotyledons rises before parturition (Liggins \& Grieves, 1971).

The high concentrations of OCS between Days 90 and 130 of pregnancy could be related to mammogenesis and lactogenesis. Mammogenesis in ewes rendered hypoprolactinaemic is apparently normal (Djiane, Kann, Delouis \& Martal, 1975; Martal \& Djiane, 1977) and can be attributed to OCS. Lactose synthesis in the sheep mammary gland begins after about Day 95 of pregnancy (Denamur, 1965), the time at which there is a large increase in OCS production. Purified OCS (Martal \& Djiane, 1975) has been shown to have lactogenic activity in vitro by its effects on the histology of mammary gland tissue of pseudopregnant rabbits and on lactose synthetase activity and casein synthesis (Martal et al., 1976).

The hormonal regulation of fetal"growth is not clear (Charrier, 1973) but growth is only delayed after hypophysectomy of fetuses after Day 93 (Liggins \& Kennedy, 1968), whereas growth hormone has been found in the fetal pituitary (Stokes \& Boda, 1968) and blood (Bassett, Thorburn \& Wallace, 1970 ) from Day 50 of pregnancy. It seems possible that a growth hormone-like substance is secreted by the placenta. OCS binds to growth hormone receptors from liver (Handwerger et al., 1974; Chan et al., 1976; Martal \& Djiane, 1977) and has been shown to increase body weight and the width of the epiphyseal cartilage of the tibia in hypophysectomized rats (Chan et al., 1976; Martal \& Djiane, 1977). In the first half of pregnancy, therefore, OCS may regulate fetal growth, while in the second half OCS and fetal growth hormone may have complementary effects.

We thank Mrs Nicole Chene for her expert technical assistance; Dr Guy Kann for the prolactin radioimmunoassay, and Professor Hubert Clauser for numerous suggestions and for reading the manuscript.

\section{References}

Alexander, G. (1964) Studies on the placenta of the sheep (Ovis aries, L.), placental size. J. Reprod. Fert. 7, 289-305.

BASSETT, J.M., OxBorrow, T.J., SmIrH. I.D. \& THORBURN, G.D. (1969) The concentration of progesterone in the peripheral plasma of the pregnant ewe. $J$. Endocr. 45, 449-457.

Bassett, J.M., Thorburn, G.D. \& Wallace, A.L.C. (1970) The plasma growth hormone concentration of the foetal lamb. J. Endocr. 48, 251-263.

Bolme, I., Boguslawski, S. \& CaIne, J. (1975) The translation of a Human Placental Lactogen mRNA fraction in heterologous cell-free systems: the synthesis of a possible precursor. Biochem. Biophys. Res. Commun. 62, 103-109.

Boshier, D.P. (1969) A histological and histochemical examination of implantation and early placentome formation in sheep. J. Reprod. Fert. 19, 51-61.

Challis, J.R.G. (1971) Sharp increase in free circulating oestrogens immediately before parturition in sheep. Nature, Lond. 289, 208.

ChAN, J.S.D., RoberTson, H.A. \& Friesen, H.G. (1976) The purification and characterization of ovine placental lactogen. Endocrinology 98, 65-76.

Charrier, J. (1973) Evolution foetale et postnatale du contenu en hormone de croissance de l'hypophyse ovine. Annls Biol. anim. Biochim. Biophys. 13, 155163.

Denamur. R. (1965) Les acides nucléiques et les nucléotides libres de la glande mammaire pendant la lactogénèse et la galactopoièse. In Proc. 2nd Int. Congr. Endocr., London, Part I, pp. 434-462. I.C.S. No. 83. Excerpta Medica, Amsterdam.

Denamur, R. (1973) Facteurs lutéotrophiques chez la Brebis. In Le Corps Jaune, pp. 213-223. Masson, Paris.

Denamur, R. \& Martinet, J. (1955) Effets de l'ovariectomie chez la Brebis pendant la gestation. C. r. Séanc. soc. Biol. 149, 2105-2107.

Denamur, R., KANN, G. \& ShORT, R.V. (1971) How does the corpus luteum of the sheep know that there is an embryo in the uterus? In Studies in the Sheep: the Endocrinology of Pregnancy and Parturition, pp. 2-4. Ed. C.G. Pierrepoint. Alpha Omega Alpha, Cardiff.

Denamur, R., Martinet, J. \& Short, R.V. (1973) Pituitary control of the ovine corpus luteum. $J$. Reprod. Fert. 32, 207-220.

DuIANE, J. \& KaNN, G. (1975) Mise en évidence de l'activité lactogène et mesure dans le sérum de l'activité prolactinique du placenta chez la Brebis au cours de la gestation. C. r. hebd. Séanc. Acad. Sci., Paris 280, 2785-2788.

Duiane, J., Kann, G., Delouis, C. \& Martal, J. (1975) Placental lactogenic hormone: plasma levels in Ruminants. Study of its role on mammogenesis and lactogenesis in the Ewe. In Proc. Int. Symp. on Growth Hormone and Related Peptides, Milan, Suppl. 1, p. 128. Ricerca Scientifica Ed. Educazione Permanente, Milan. 
Dubois, M., Martal, J. \& DJiane, J. (1976) Immunofluorescence localization of placental lactogen. In Proc. 5th Int. Congr. Endocr. Hamburg, p. 25, Brühlsche Universitäts druckerei, Giessen.

ForsYTH, I.A. (1972) Use of a rabbit mammary gland organ culture system to detect lactogenic activity in blood. In Lactogenic Hormones, pp. 151-167. Eds G.E.W. Wolstenholme \& J. Knight. Churchill Livingstone, Edinburgh.

Gustavin, B. (1975) Release of lysosomal acid phosphatase into the cytoplasm of decidual cells before the onset of labour in humans. Br.J. Obstet. Gynaec. 82, 177-181.

Handwerger, S., Maurer, W., Barrett, J., Hurey, T. \& Fellows, R.E. (1974) Evidence for homology between ovine and human placental lactogens. Endocr. Res. Commun. 1, 403-413.

Hubert, C. \& CÉDART, L. (1975) Isolation and in vitro translation of human placental lactogen messenger RNA from human term placenta. Nucleic Acids Res. 2, 1903-1910.

Josimovich, J.B. (1963) The luteotrophic, immunologic and electrophoretic properties of human placental lactogen. Endocrinology 73, 410-420.

KANN, G. (1971) Dosage radio-immunologique de la prolactine plasmatique chez les ovins. C. r. hebd. Séanc, Acad. Sci. Paris 272, 2808-2811.

Kelly, P.A., Robertson, H.A. \& Friesen, H.G. (1974) Temporal patterns of placental lactogen and progesterone secretion in sheep. Nature, Lond. 248, 435437.

Liggins, G.C. \& Grieves, S.A. (1971) Possible role of prostaglandin $\mathrm{F}_{2 \alpha}$ in parturition in sheep. Nature, Lond. 232, 629-631.

Liggins, G.C. \& Kennedy, P.C. (1968) Effects of electrocoagulation of the foetal lamb hypophysis on growth and development. J. Endocr. 40, 371-381.

Martal, J. \& Diane, J. (1975) Purification of a lactogenic hormone in sheep placenta. Biochem. Biophys. Res. Commun. 65, 770-778.

Martal, J. \& DJiane, J. (1977) Mammotrophic and growth promoting activities of a placental hormone in sheep. $J$. Steroid Biochem. (in press).

Martal, J., Duiane, J. \& Delouis, C. (1975) Isolation and characterization of an ovine placental lactogenic hormone. In Proc. Int. Symp. on Growth Hormone and Related Peptides, Milan, Suppl. 1, p. 125. Ricerca Scientifica Ed. Educazione Permanente, Milan.

Martal, J., Duiane, J. \& Delouis, C. (1976) Purification and lactogenic activity of an ovine placental hormone. Annls Biol. anim. Biochim. Biophys. 16, 162.

Moor, R.M. \& Rowson, L.E.A. (1966a) The corpus luteum of the sheep : functional relationship between the embryo and corpus luteum. J. Endocr. 34, 233-239

MooR, R.M. \& Rowson, L.E.A. (1966b) The corpus luteum of the sheep : effects of removal of the embryos on luteal function. $J$. Endocr. 34, 497-502.

RoBerTs, E.M. (1966) The use of intravaginal sponges impregnated with 6 methyl-17-acetoxy progesterone (MAP) to synchronize ovarian activity in cyclic Merino ewes. Proc. Aust. Soc. Anim. Prod. 6, 32-37.

Rolschau, J., Date, J., Kristoffersen, K., Pedersen, G.T. \& UlRICH, M. (1975) Correlation between human chorionic somatomammotrophin and placental weight. Acta obstet. gynaec. scand. 54, 341-346.

SaXena, B.N., Emerson, K. \& Selenkow, H.A. (1969) Serum Placental Lactogen (HPL) levels as an index of placental function. New Engl. J. Med. 281, 225-231.

ScIarRa, J., SHERWOOD, L.M., VARNA, A.A. \& LUNDBERG, W.B. (1968) Human Placental Lactogen (HPL) and placental weight. Am. J. Obstet. Gynec. 101, 413-416.

SEPPÄLÄ, M. \& Ruoslahti, E. (1970) Serum concentration of Human Placental Lactogenic Hormone (HPL) in pregnancy complications. Acta obstet. gynaec. scand. 49, 143-147.

Shiu, R.P.C., Kelly, P.A. \& Friesen, H.G. (1973) Radioreceptor assay for prolactin and other lactogenic hormones. Science, N. Y. 180, 968-970.

Singer, W., Desjardins, P. \& Friesen, H.G. (1970) Human placental lactogen. An index of placental function. Obstet. Gynec., N. Y. 36, 222-232.

STOKES, H. \& BODA, J.M. (1968) Immunofluorescent localization of growth hormone and prolactin in the adenohypophysis of fetal sheep. Endocrinology 83, 1362-1366.

Szego, C.M. (1974) The lysosome as a mediator of hormone action. Recent Prog. Horm. Res. 30, 171233.

Received 3 August 1976 